\title{
E-Learning and Economic Well-Being of Graduates: Applying the Human Capital Earning Function to Distance Education
}

\author{
Jumah Ahmad Alzyadat \\ Department of Finance and Banking, College of Business Administration, Dar Aluloom \\ University, Riyadh, KSA. \\ jalzyadat@dau.edu.sa
}

\begin{abstract}
The study aims to evaluate the effectiveness of e-learning in raising the income level of graduates. Based on a sample of the distance education program students in the Bachelor of Business Administration. The study applies the net present value, and regression model to estimate the Human Capital Earnings Function presented by Mincer (1974). The results showed that the NPV of the expected cost and earnings for graduates that the program will cause an improvement of the standard of living of graduates. Moreover, the regression results indicate that the most important factors affecting the expected wages are those objective factors such as experience and job stability, as they are superior to subjective factors such as marital status and age, the technical expertise comes between these two groups. The study recommends more use of modern technologies in the field of distance education, for all societies without restrictions of time or place, in order to achieve the spread of knowledge, to raise the efficiency and income of workers in the economy. Provide the opportunity for those who were unable to continue their university education, due to socioeconomic conditions.
\end{abstract}

Keywords: E-learning, Distance Education, Human Capital Earnings Function, Economic WellBeing

\section{How to Cite:}

Alzyadat, J. A. (2022). E-Learning and economic well-being of graduates: applying the human capital earning function to distance education. International Journal of Business, Management, and Economics, 3(1). 81 - 94. DOI: https://doi.org/10.47747/ijbme.v3i1.502

\section{Introduction}

Economists have noted the long relationship between workers 'education level and their wages (Vinovskis, 1970). The relationship has been formalized in many recent studies on the rate of return to education and the contribution of education to worker productivity. Empirical studies 
generally indicate that an increased level of education of an individual is associated with higher productivity. The study by Fleisher et al., (2011) showed that an additional year of schooling raises marginal product by $30.1 \%$. Thus, it will improve opportunities in the labor market; this explains the high wages of educated workers. Therefore, it can be said that learning is the key to success and growth in an individual's life.

The Information and Communication Technology ICT revolution lead to a significant reduction in barriers to information access and communication between people, institutions, and countries (Khan, \& Williams, 2006), Also the emergence of new types of learning and teaching, further entrench the concept of individual or self-education. Where the learner continues his learning according to his capacity, ability, speed of learning, and according to his previous experiences and skills. E-learning is considered one of the advanced forms of distance learning, especially computer-based education. e-learning has built on the extensive use of advanced information and communication technologies to deliver learning and instruction (Navimipour \& Zareie, 2015), Elearning gives a flexible and easy environment to the students less cost, convenient time and place to study. User perception and readiness play an important role in e-learning effectiveness in both developing and developed countries (Naresh \& Reddy, 2015).

Within the framework of societies to benefit from the knowledge economy, there have recently wide changes in university education, especially to provide different groups of students with new skills and qualifications that enable them to compete in the labor market. Therefore, the educational process has undergone an in-depth review so that information technology is part of the structure of the education strategies, and this explains the widespread concepts of e-learning, online education, and the virtual university.

Recently, wide changes have taken place in education, especially in light of what the world is witnessing these days from the Coronavirus COVID-19 pandemic and the imposition of lockdown and social distancing in most countries of the world, the pandemic changed the lives of millions of people around the world (Alzyadat \& Asfoura, 2021). The labor market began, through its need for new skills and qualifications, to impose new trends and specializations that meet the needs of the economy. Therefore, the educational process has undergone a review to keep pace with modern requirements and available technologies, such as e-learning and direct education that depends on the Internet. This is to employ modern technologies in the field of elearning in university education, for all their categories and segments without restrictions of time or place. What drives the growing trend towards e-learning are the benefits it provides. Which should be known exactly where these benefits lie. In addition, this type of education witnesses the increasing demand of all segments of society for e-learning. The characteristics of this type of education in terms of its flexibility, economic effectiveness, and its elimination of place and time barriers contribute to enhancing the demand of all segments of society for e-learning services. In light of the increase in the demand for this type of education. E-learning can be an opportunity to encourage the information and communication technology policy in universities. That can favor their organizational adaptation to digital requirements in terms of better performance, to offer students to continue education with a better match with the production 
needs in the knowledge economy (Vilaseca \& Castillo, 2008). Nowadays the system of education faces the task of building a flexible system able to quickly adapt to the learning of specialists in the dynamically changing world, with a high level of quality. Information and communication technologies based on which there is a process of creation of the systems of remote learning capabilities to provide flexibility and high quality of learning can play an important role in the creation of such system (Bataev, 2017).

E-learning can be seen as the umbrella for many activities and applications as computer-based education. Using the web and virtual classroom, but its scope is narrower than the term distance education, which may include in addition to that education by correspondence education that depends on regular mail channels. E-learning, whether remotely or in the important semester, is the use of technology of all kinds in the delivery of information to the learner in the shortest time, with the least effort and the greatest benefit. Moreover, the remote study is a derivative part of the electronic study. In both cases, the learner receives the information from a place far from the teacher. In other words, e-learning depends mainly on computers and networks to transfer knowledge and skills. Its applications include web-based learning, computer-based learning, virtual classrooms, and digital collaboration. Lesson content is provided online, in audio, video, and CD-ROM.

According to the method of providing the educational service, there is a synchronous course and an asynchronous course. In the first case, all participants enter the network at an agreed specific time and communicate in a live broadcast, this system is also called distance education, this service requires high-quality communication and networking. As for asynchronous education, it does not require that all individuals be present on the network at the same time, but each of them can choose the time that is suitable.

E-learning in its modern applications is not necessarily separate from traditional teaching in the classroom. Many programs in major universities contain components received inside the lecture hall and others received by the student remotely, where the student is obligated to come personally to the university for a certain period to receive the courses. Then the student returns to his country and completes the program through e-learning techniques, under the guidance and supervision of the faculty. That is, e-learning is an expansion of the concept of the teaching and learning process to transcend the traditional classroom boundaries and launch a rich multisourced environment, in which educational technologies have a fundamental role in the educational process.

\section{Literature Review}

The neoclassical growth model proposed by Robert Solow (Solow 1957), asserted that the impact of education and human capital could be studied through their effect on technological progress. According to this theory, such that technology improves, the efficiency and productivity of labor. Meanwhile, improvement in technology can be seen in terms of human capital (education and skills development) (Khan, \& Williams, 2006). The traditional theory of 
International Journal of Business, Management, and Economics

e-ISSN 2746-1351

Vol. 3 No. 1, February 2022

Human capital investment developed by Becker (1962) and Mincer (1974) views education and training as the major sources of human capital accumulation, that, have a direct and positive effect on individuals' lifetime earnings (Nasir \& Nazli 2010). From the economic point of view, and the empirical studies, an increase in the level of education of an individual is associated with an increase in his productivity, thus improved opportunities in the labor market, this explains the high wages of more educated workers. Education has an important effect on wages but it is not clear whether this is because education raises productivity or because education is simply a signal of ability (Chevalier et al., 2004). The labor factor is the basis of the factor of production in the production function. Hence, the importance of investing in the human capital in an integrated and comprehensive manner, supporting it with a broad and dynamic training and education industry that keeps pace with the latest sciences and methods. Depending on its course in this direction on the concept of education and training. some studies use the internal rate of return to education to assess whether an educational expenditure should be expanded or contracted (Heckman et al., 2008). Education remains a profitable investment for individuals. On average, another year of education produces a rate of return to education in excess of $5-8 \%$ a year (Patrinos, 2016). The study by Nasir and Nazli (2010) found that the additional year of education raises the individual's monthly income by $7.3 \%$,

Expanding scientific and technical knowledge that raises labor productivity and production inputs. Where the systematic application of scientific knowledge to produce commodities led to a significant increase in the value of education, technical education, and training as the growth of knowledge became embodied in the production factors (Becker, 2009). Education is seen as an investment in the stock of human skills or the formation of human capital (Mincer, 1975). A country's stock of skills is fundamental to the potential for economic growth in a highly competitive international environment. Human capital is a key determinant of income inequality, and it is more important than ever as wages for skills rise (Burgess, 2016). Education can affect wages rates or wages per unit of time period operate (Mincer, 1975).

E-learning accelerates economic growth and per capita income, where E-learning is accelerating the convergence of human capital suitable for a modern market economy. Given the low costs. E-learning increases the options for students to learn and acquire skills that are relatively expensive in the economy (Kejak, \& Ortmann, 2000). Olakulehin, (2008) found distance education as a fundamental means for human capital development in Nigeria The variance in the total productivity factors productivity TFP across industries refers reflects the efficient use of the available resources Alzyadat, et al (2021). which reinforces the hypothesis that there are complementarities between technical and organizational change and skilled labor inputs to explain productivity gains at the industry level. (Castillo-Merino, \& Sjöberg, 2008). Studies have shown that these developments have led to an improvement in the productivity and efficiency of various business enterprises (Alzyadat, \& Almuslamani, 2021). E-learning has the potential to make the acquisition of human capital cheaper and easier. Also, ensuring -high quality education within the reach of employees also has the potential to help alleviate poverty by empowering the socially disadvantaged and the less fortunate in society including low-income groups, the disabled, the sick, and women affected by cultural and religious bias. (Khan, \& 
Williams, 2006). The evidence suggests e-learning companies are making inroads because of cost savings, an estimated one-half to two-thirds of the costs that employers would have to incur were they to send their employees to traditional education and training courses (Kejak, \& Ortmann, 2000). one factor that e-learning is less expensive is the opportunity costs of going to school full-time and/or travel-related and time costs (Kejak, \& Ortmann, 2000).. Distance education is the tool that will enable benefit is not just education but the even distribution of educational benefits among a country's socioeconomic groups, in both rural and urban areas. Digital technologies have been able to meet educational requirements by providing a digital infrastructure that can be expanded anywhere in the world. The presence of this infrastructure with the appropriate software tools means the completion of the tools for carrying out the educational process, as the Internet is seen as a mediator who provides the study material to anyone, anywhere, and at any time. That is why advanced universities in the world are obligated to network university facilities internally and provide Internet connection service from the classroom, laboratories, libraries, and even university residences as well. The continuous decrease in the costs of owning and operating the webserver, along with the continuous improvement in specifications, means providing the opportunity for medium and less advanced universities to launch their own websites to provide educational services to their students. On the other hand, Web technologies in education are available to everyone and are constantly evolving. These technologies allow the learning process to be facilitated effectively.

The incentives for e-learning and its applications come from both the demand and supply sides. On the demand side, population growth is extending the education market to individuals desiring all levels of education. so, the increasing demand will open the way for e-learning applications. many individuals want to enroll in university education but are unable to do so due to Work pressure family obligations, or physical disability. this leads to the investment of time in education without additional costs. The knowledge revolution has produced explosive growth in the amount of information that we deal with in our life. individuals seek to pursue new developments in their field of interest through continuous education. With the spread of modern knowledge-intensive devices in various production units, workers find themselves needs to take advantage of e-learning to develop the skills of searching for information in the available sources and critical thinking to evaluate that information, as well as the skills of communicating with others to exchange information in the circumstances of the flood of information in which we live. On the supply side, the information technology sector development during the past two decades helped in promoting economic development. The increase in applications for admission to universities is leading to pressure to expand existing facilities and build new facilities to accommodate students and educational services. Therefore, the universities seek to search for new channels that are less expensive.

\section{Research Method}

This study tries to estimate the expected return for students from enrolling in an e-learning program that awards a bachelor's in business administration. By using the econometric model, 
this return is represented in the increase in the wages due to obtaining a university qualification or obtaining a new job with this qualification. The study also aims to identify the most important factors in determining the expected return after the end of the program.

\subsection{Study population and sample}

The study population consists of male and female students who study in a business administration program in distance education at a Saudi university. At the beginning of each semester, students attend only three lectures in each course, then the program is completed remotely through electronic channels that allow the student and teacher to communicate and continuously participate, where the faculty member uploads the course description and a full copy of the lectures with a full explanation of the educational content supported by what suits the educational objectives of Multimedia. It also uploads self-evaluation tests electronically to make the student able to evaluate his understanding of the study units separately and the course as a whole unit. There is also a virtual classroom service that allows communicating with the instructor in a live broadcast at predetermined dates. The program is classified within the Blended Learning systems, where students attend intensive introductory lectures with faculty members and then complete the program via electronic means. The main source of data is a questionnaire designed to identify the different characteristics of the student population and the expected change in income after the completion of the bachelor's program. The questionnaire was distributed to all male and female students at all academic levels during the first semester exam period. Table 1 summarizes the numbers of completed questionnaires and some other indicators.

Table 1. Preliminary indicators from male and female students' data

\begin{tabular}{|l|r|r|r|}
\hline Item & Male & Female & Total \\
\hline $\begin{array}{l}\text { The number of students registered in the } \\
\text { program }\end{array}$ & 2430 & 1690 & 4120 \\
\hline Sample Size & 1099 & 706 & 1805 \\
\hline $\begin{array}{l}\text { Number of Determined the Expected Salary } \\
\text { Increase }\end{array}$ & 916 & 222 & 1138 \\
\hline $\begin{array}{l}\text { The average expected increase in salary per } \\
\text { month after completing the program }\end{array}$ & 2082.6 & 4141.7 & 2484.3 \\
\hline Average age & 31 & 25 & 30 \\
\hline
\end{tabular}

\subsection{Measuring the Effectiveness of E-learning}

Measuring the effectiveness of e-learning in raising the level of income for students, the study used the net present value (NPV) of the students 'investment in the Bachelor of Business Administration program by calculating each of the costs and benefits. The study also relied on a regression model based on the Mincer earnings equation developed by Becker (1964) and 
Mincer (1974) which remains an accurate benchmark for estimating wage determination equations (Lemieux, 2006). Where the multiple regression model formula links the expected wage as a dependent variable, the number of years of education, experience, and personal characteristics of the individual as independent variables. The model was developed to achieve the objectives of the study by excluding the number of years of education. Moreover, the use of variables: (gender, marital status, employer, number of years of experience, job stability, economic role in the family). Also added to the model indicators related to e-learning, which are those related to computer and internet skills.

\subsection{The Net Present Value (NPV)}

The NVP is one of the criteria for judging the investment decision in a particular project. to measure the present value of payments to be realized in the future (Cecchetti \& Schoenholtz, 2011). to estimate the net present value of a student's investment in the Bachelor of Business Administration program. Both costs and benefits are calculated. On the costs side, the tuition fees and other costs incurred by the individual to complete the program are calculated, including the opportunity cost of the time he devoted to studying instead of earning more income. The direct benefits are the expected net increase in income because of raising the level of education. These costs and benefits are calculated on an annual basis and are included in the NPV.

Assumptions underlying the NPV calculation in this study, that the student finishes his studies according to the plan within four years without delay. The highest income, whether through promotion or employment, is achieved in the year following graduation; the new salary continues without increasing the length of the estimated period, the average age of the student indicated in the table is when starting the program. All individuals retire at the age of sixty years from the available data monthly, the expected increase in the salary is calculated annually, and it is assumed that it will be achieved at the end of the year. Regarding program costs, the assumption is that the student costs are the tuition fees only, because other types of costs are secondary, such as transportation to attend lectures or introductory meetings). There is one cost-of-funds rate which is the basis for discounting all the annual flows. Calculate the net present value the formula used to calculate NPV is:

$$
N P V=\sum \frac{B_{t}-C_{t}}{(1+r)^{t}}
$$

Where NPV $=$ Net Present Value. $B \neg t=$ annual expected benefits and does not start until graduation. $\mathrm{Ct}=$ annual costs associated with the learning activity during the program. $\mathrm{r}=$ discount rate. On the issue of maintaining the increase in income, there is an assumption that is a decline in the importance of the university degree within five years of graduation. The assumption is based on the expiration of the certificate, which means that the value of the professional or academic certificate ends after a few years due to the explosion of information and the increasing importance of continuous learning and the accumulation of experiences. This Linked to another assumption, which is that the employee's persistence and obtaining an increase 
in income are related to productivity, and the ability to convert acquired knowledge into achievements to achieve job objectives efficiently. With regard to the discount rate, the definition of this rate has been adopted as the expected annual return on a safe investment from risk and this has multiple applications. It may be the average return expected for depositing an amount of money with the bank for a year or an average annual return on investment in the stock market in the risk-free stock. There may be controversy over the distinction between the discount rate for study costs and the discount rate for estimating the present value of the expected returns after the program ends, but for simplicity, we assume that it is one.

\subsection{Regression Model}

To determine the factors affecting the expected wage after graduation. There are many factors that affect wages; these factors are distributed among the demand and supply sides of the labor market, in addition to the fact that the regulatory, institutional and legal framework largely governs this market. This model focuses on factors related to the supply side, i.e. the characteristics of the job seekers and the employees themselves. Perhaps the most prominent contributions in this field are the model presented by Mincer, where he put forward a multiple regression model formula linking wage as a dependent variable, the number of years of education, experience, and personal characteristics of the individual as independent variables (Mincer, 1974). Excluding the number of years of education because the study population is among those with intermediate qualifications seeking to obtain a bachelor's degree in business administration, meaning that they have approximately the same number of school years, therefore the parameter of this variable will be not significant. In addition, indicators related to elearning were added to the estimating formula, which is those related to computer skills.

The regression equation takes the following form:

$$
\ln W=\alpha+\beta_{1} G+\beta_{2} A+\beta_{3} S+\beta_{4} M+\beta_{5} X+\beta_{6} T+\beta_{7} E+\beta_{8} C+U
$$

Where W: Income (the expected wages after graduation) which is the dependent variable in the model. Since most of the students in the selected program are employed, a question was asked about the expected increase in wages after graduation. G: gender (male or female), A: age, S: Social status, M: Employer (military or civilian), X: Number of years of work experience, T: Job stability (permanent or temporary job). E: The economic role in the family is the breadwinner or not, $\mathrm{C}$ : Experience in computers and the Internet. The parameter $\alpha$ is the intersectional parameter, $\beta$ denotes the percentage change in income as a result of a one-unit change in the corresponding independent variable (Vilaseca \& Castillo, 2008). U is the stochastic variable that assimilates the change in the dependent variable that is not explained by the independent variables included in the regression model. 


\section{Results and Discussion}

The sample size is 1805 (all male and female students who responded to the questionnaire. After excluding all cases with missing data, including those who omitted to mention the expected salary after graduation, thus the number of liquidated cases reached 965 only. Perhaps the most striking thing is the large disparity in the ages of students, ranging between 18 and 50 years old. In addition, some students have a long experience in their current job of up to 28 years.

Table 2 Descriptive Statistics

\begin{tabular}{|c|l|l|l|l|l|}
\hline The variable & $\mathrm{N}$ & Minimum & Maximum & Mean & $\begin{array}{c}\text { Std. } \\
\text { Deviation }\end{array}$ \\
\hline $\mathrm{W}$ & 1138 & 7.31 & 10.82 & 8.8908 & .45482 \\
$\mathrm{G}$ & 1805 & .00 & 1.00 & .3911 & 48814 \\
$\mathrm{~A}$ & 1805 & 18.00 & 50.00 & 28.1590 & 6.16367 \\
$\mathrm{~S}$ & 1805 & .00 & 1.00 & .5795 & .49378 \\
$\mathrm{M}$ & 1805 & .00 & 1.00 & .1058 & .30769 \\
$\mathrm{X}$ & 1805 & .00 & 28.00 & 5.1684 & 5.78422 \\
$\mathrm{~T}$ & 1155 & .00 & 1.00 & .8511 & .35616 \\
$\mathrm{E}$ & 1804 & .00 & 1.00 & .6020 & .48962 \\
$\mathrm{C}$ & 1804 & .00 & 30.00 & 19.8104 & 5.91046 \\
Valid N & 965 & & & & \\
(listwise) & & & & & \\
\hline
\end{tabular}

The NPV of the expected cost and revenue after the end of the program is more than 93 thousand riyals for the male student and 208 thousand riyals for the female student, meaning that from an economic point of view and assuming that the expected increase in income lasts only 5 years, this program is a reason. Practically to improve the standard of living for graduations. If we assume that the employment system is the traditional rigid system that does not require continuous learning or seriously updating knowledge or skills, then the impact of the bachelor's degree extends to the end of the student's career. Whereas the average age of a male student is 31 years and a female student is 25 years old, the number of years of work after completing the bachelor's program reaches 29 years for a male student and 35 years for a female student on average. By recalculating the NPV, it is about 580 thousand riyals for the student and about 1.5 million riyals for the female student on average

The $\mathrm{R}$ coefficient indicates a relatively strong positive correlation between the observed and estimated values (0.615). R Square coefficient indicates that about $38 \%$ of the change in the dependent variable (wage) is due to the explanatory variables included in the model, they are mainly related to the characteristics of individuals, i.e. the supply side of the labor market. The unexplained $62 \%$ is due to factors on the demand side as well as the structural, regulatory and legal constraints that govern the labor market. 
Table 3. Model Summary

\begin{tabular}{|c|c|c|c|c|}
\hline \multirow[t]{2}{*}{ Model } & $\mathbf{R}$ & \multirow[t]{2}{*}{ R Square } & \multirow{2}{*}{\begin{tabular}{|l} 
Adjusted \\
Square
\end{tabular}} & \multirow{2}{*}{$\begin{array}{l}\mathrm{R} \mid \begin{array}{l}\text { Std. Error of the } \\
\text { Estimate }\end{array} \\
\end{array}$} \\
\hline & $\mathrm{W}>0($ Selected $)$ & & & \\
\hline & $615^{\mathrm{a}}$ & .378 & 372 & .33126 \\
\hline
\end{tabular}

a. Predictors: (Constant), G, A, S, M, X, T, E, C

The variance analysis shows that the dependent variable is explained by the model's significance, as compared to the unexplained variance. The model passed the F-test where the assumption that all the model parameters were zero at a significance level of less than $1 \%$ was rejected.

Table 4. ANOVA

\begin{tabular}{|c|l|l|l|l|l|l|}
\hline Model & Sum of Squares & Df & Mean Square & F & Sig. \\
\hline $\begin{array}{l}\text { Regression } \\
\text { Residual }\end{array}$ & 63.772 & 9 & 7.086 & 64.574 & $.000^{c}$ \\
Total & 104.793 & 955 & 110 & & \\
\hline
\end{tabular}

The results of the regression estimate in the Table 5 indicate that the gender factor G: for female students, the total expected income will be approximately $22 \%$ less, while other factors remain the same. Although the expected increase in income will be greater compared to male students, the total expected income of female students remains lower than that of male students in the mentioned ratio. age is one of the factors contributing to determining the expected income after graduation, every year of increase in the age of the graduate increases the probability of increasing his income by $0.6 \%$. The coefficient of marital status (S) is significant, which indicates that the married has a chance to increase his income by about $9 \%$ more compared to the single student.

The coefficient of Workplace (M) is significant; thus, the military has a $14.2 \%$ greater chance of achieving higher incomes compared to the non-military. The number of years of experience (X), the results show that each year of additional experience of the student corresponds to an increase in income of about $3 \%$. Job stability $(\mathrm{T})$ is a very influential factor, as those with permanent jobs have a wage increase up to $21 \%$ compared to those with temporary jobs. The parameter estimate for the economic role in the family (E), is not statistically significant, this indicates that being a breadwinner or non-breadwinner does not affect the expected level of income after completing university studies. The estimated parameter for Computers and Internet Experience (C) states that the greater the experience of dealing with computer applications and the Internet, the greater the individual's chance of obtaining a higher income.

Comparison of the relative importance of the variables in the Table 5 shows that the most important variable experiences, followed by job stability, gender, workplace, and experience in the field of computers and the Internet, then marital status, and finally the age. It is generally observed from these indicators that objective aspects such as experience and job stability 
outperform subjective factors such as marital status and age, and technical expertise comes in between.

Table 5. Regression results

\begin{tabular}{|c|c|c|c|c|c|}
\hline & \multicolumn{2}{|c|}{$\begin{array}{l}\text { Unstandardized } \\
\text { Coefficients }\end{array}$} & \multirow{2}{*}{\begin{tabular}{|l} 
Standardized \\
Coefficients \\
Beta
\end{tabular}} & \multirow[t]{2}{*}{ t statistics } & \multirow[t]{2}{*}{ Sig. } \\
\hline & $\mathrm{B}$ & Std. Error & & & \\
\hline (Constant) & 8.189 & .113 & & 72.669 & .000 \\
\hline $\mathrm{G}$ & $-.216-$ & .044 & $-.137-$ & $-4.874-$ & .000 \\
\hline $\mathrm{A}$ & .006 & .004 & .078 & 1.715 & .087 \\
\hline $\mathrm{S}$ & .087 & .029 & .094 & 3.013 & .003 \\
\hline $\mathrm{M}$ & .142 & .030 & .126 & 4.690 & .000 \\
\hline$X$ & .027 & .003 & .343 & 7.929 & .000 \\
\hline $\mathrm{T}$ & .208 & .035 & .173 & 5.950 & .000 \\
\hline$E$ & $-.066-$ & .050 & $-.037-$ & $-1.315-$ & .189 \\
\hline $\mathrm{C}$ & .011 & .003 & .142 & 3.048 & .002 \\
\hline
\end{tabular}

\section{Conclusion}

The study applies NPV to estimate the effectiveness of e-learning in raising the level of income for students. The results show that the current value of the cost flows and the expected increase in income after graduation reaches - on average - 580 thousand riyals for the male student and 1.5 million riyals for the female student, assuming the continuation of the increase to the end of the career. That is, from the economic point of view, the program is a practical reason to improve the standard of living for its participants. As for the factors affecting the amount of expected wage after graduation, the study shows that the expected income for female students is approximately $22 \%$ less. The age factor contributes to a limited extent in determining the expected income after graduation, as an increase in the age of the graduate increases the probability of increasing his income by $0.6 \%$. The marital status plays an important role in determining the expected income after graduation, as married people have the opportunity to increase their income by about $9 \%$ more compared to single people. The results of the model estimation also indicated that the expected income was affected by the number of years of experience, every year of additional experience of the student leads to an increase in income by about 3\%. The results also indicate that job stability is a very influential factor, as those with permanent jobs up to $21 \%$ more salary increase than those with temporary jobs. The results indicate that the workplace has an important role in determining the expected income after graduation, as military personnel has a $14.2 \%$ greater chance of achieving higher incomes compared to non-military. As for the indicators related to e-learning, it was found that the more experience dealing with computer applications and the Internet, the greater the individual's chance of obtaining a higher income. With regard to the relative importance of these variables, it is noted that aspects such as experience and job stability are superior to personal factors such as 
marital status and age, and technical expertise comes in an intermediate place between them. The study recommends that individuals should be encouraged to take advantage of modern technologies in the field of e-learning and distance education in universities and scientific institutes to obtain an education without being bound by time or place, in order to achieve the spread of science and knowledge. to raise the efficiency of work in all sectors, especially with the availability of an economic incentive represented in increasing income After obtaining the university degree through e-learning channels. The study recommends that social conditions or age should not be considered an obstacle to benefiting from these university programs and obtaining a suitable income after graduation.

\section{References}

Alzyadat, J. A., \& Almuslamani, M. S. (2021). The Role of Technological Progress in the Distribution sector: Evidence from Saudi Arabia Wholesale and Retail Trade Sector. Journal of Distribution $\quad$ Science, 19(3), 15-23. https://doi.org/10.15722/JDS.19.3.202103.15

Alzyadat, J. A., \& Asfoura, E. (2021). The Effect of COVID-19 Pandemic on Stock Market: An Empirical Study in Saudi Arabia. The Journal of Asian Finance, Economics and Business, 8(5), 913-921. https://doi.org/10.13106/JAFEB.2021.VOL8.NO5.0913

Alzyadat, J. A., Alotaibi, A. F., Almubdel, A. H., \& Alrshaid, N. A. (2021). Estimating total factor productivity in the Saudi Arabia construction sector. Amazonia Investiga, 10(40), 45-53. https://doi.org/10.34069/AI/2021.40.04.5

Bataev, A. V. (2017, November). Electronic learning as the condition of improvement in quality of learning of engineering and economic personnel. In 2017 IEEE VI Forum Strategic Partnership of Universities and Enterprises of Hi-Tech Branches (Science. Education. Innovations)(SPUE), 103-106. https://doi.org/10.1109/IVForum.2017.8246063

Becker, G. S. (1962). Investment in human capital: A theoretical analysis. Journal of political economy, 70(5, Part 2), 9-49.

Becker, G. S. (1975). Front matter, human capital: a theoretical and empirical analysis, with special reference to education. In Human Capital: A Theoretical and Empirical Analysis, with Special Reference to Education, Second Edition (pp. 22-0). NBER.

Becker, G. S. (2009). Human capital: A theoretical and empirical analysis, with special reference to education. University of Chicago press.

Burgess, S. M. (2016). Human capital and education: The state of the art in the economics of education. Discussion Papers, No. 9885, Institute for the Study of Labor (IZA), Bonn. available at: http://hdl.handle.net/10419/141644

Castillo-Merino, D., \& Sjöberg, M. (2008). A theoretical framework for the Economics of Elearning. RUSC. Universities and Knowledge Society Journal, 5(1), 2-11. 
Chevalier, A., Harmon, C., Walker, I., \& Zhu, Y. (2004). Does education raise productivity, or just reflect it?. The Economic Journal, 114(499), F499-F517. https://doi.org/10.1111/j.1468-0297.2004.00256.X

Fleisher, B. M., Hu, Y., Li, H., \& Kim, S. (2011). Economic transition, higher education and worker productivity in China. Journal of Development Economics, 94(1), 86-94. https://doi.org/10.1016/j.jdeveco.2010.01.001

Heckman, J. J., Lochner, L. J., \& Todd, P. E. (2008). Earnings functions and rates of return. Journal of human capital, 2(1), 1-31.

Kejak, M., \& Ortmann, A. (2000). A Way to Solve the Human Capital Mismatch Problem in Transitional Economies in Central Europe?. CERGE-EI/World Bank research. Available at: http://home.cergeei.cz/ortmann/Papers/CERGEEIresearchcompetitionsubmission2.pdf

Khan, H., \& Williams, J. B. (2006). Poverty alleviation through access to education: can elearning deliver?. .u21 Global working paper No. 002/2006 Electronic copy available at: https://ssrn.com/abstract $=1606102$

Lemieux T. (2006) The "Mincer Equation" Thirty Years After Schooling, Experience, and Earnings. In: Grossbard S. (eds) Jacob Mincer A Pioneer of Modern Labor Economics. Springer, Boston, MA. https://doi.org/10.1007/0-387-29175-X_11

Mincer, J. (1975). Education, experience, and the distribution of earnings and employment: an overview. Education, income, and human behavior, 71-94.

Mincer, J. A. (1974). The human capital earnings function. In Schooling, Experience, and Earnings (pp. 83-96). NBER.

Naresh, B., \& Reddy, B. S. (2015). Challenges and opportunity of E-learning in developed and developing countries-a review. International Journal of Emerging Research in Management \&Technology, 4(6), 259-262.

Nasir, Z. M., \& Nazli, H. (2010). Education and earnings in Pakistan. Working Papers \& Research Reports, RR-No.

Navimipour, N. J., \& Zareie, B. (2015). A model for assessing the impact of e-learning systems on employees' satisfaction. Computers in Human Behavior, 53, 475-485. https://doi.org/10.1016/j.chb.2015.07.026

Olakulehin, F. K. (2008). Open and distance education as a strategy for human capital development in Nigeria. Open Learning: The Journal of Open, Distance and eLearning, 23(2), 123-130. https://doi.org/10.1080/02680510802051939

Patrinos, H. A. (2016). Estimating the return to schooling using the Mincer equation. IZA World of Labor. http://dx.doi.org/10.15185/izawol.278 
Solow, R. M. (1957). Technical change and the aggregate production function. The review of Economics and Statistics, 312-320. https://doi.org/10.2307/1926047

Vilaseca, J., \& Castillo, D. (2008). Economic efficiency of e-learning in higher education: An industrial approach. Intangible Capital, 4(3), 191-211. http://dx.doi.org/10.3926/ic.88

Vinovskis, M. A. (1970). Horace Mann on the economic productivity of education. New England Quarterly, 550-571.

\section{Copyrights}

Copyright for this article is retained by the author(s), with first publication rights granted to the journal.

This is an open-access article distributed under the terms and conditions of the Creative Commons Attribution license (http://creativecommons.org/licenses/by/4.0/) 